\title{
MIDDLE EUROPEAN SCIENTIFIC BULLETIN \\ A healthy lifestyle in the family is an important factor in developing living standards of our people
}

ISSN 2694-9970

\author{
Siroj Ruzimuradov ${ }^{1}$ \\ ${ }^{1}$ Samarkand State University, teacher
}

\begin{abstract}
The article analyzes a healthy environment developing issues in the family that has been shaping for centuries. It provides recommendations for upbringing children in a family setting and raising them healthy.

Key words: family, children, parents, healthy environment, national values, mutual respect, school, national identity, community, healthy lifestyle.
\end{abstract}

\section{Introduction}

Ensuring sustainable socio-economic development in any society takes place in connection with improving the living standards and life quality of our people. In particular, the family is an important factor in improving the living standards and life quality of Uzbek people. From time immemorial, our people have considered the family as a sacred upbringing place. From time immemorial, our country has known that stability is possible only if the family is strong, its members are peaceful, prosperous and healthy. In almost no country young people isolation from their family environment, their homeland, and their separate assessment given the expected results. For example, each family has its own place, evolution, social appearance history. Their forms are also different.They do not completely duplicate each other. But the family is always, at all times, a whole social phenomenon that presupposes the natural biological, economic, property, legal and spiritual unity inherent in human beings.

\section{Main part}

The family is the basic society unit. The family is a great place to ensure the people or nation continuity, to preserve national values, to be able to bring up new generation. The society strength and tranquility depended on the peace and the family tranquility, and a healthy lifestyle in the society depended on the family members' sincere attitude to each other, moral upbringing. Explaining the family role in every person life, especially the children upbringing, President Shavkat Mirziyoyev said that "in today's rapidly changing conflict, it is difficult to find answers to many complex questions in social life without a thorough family issues scientific study "1. In this regard, such a worldview and morality formed among our people still reflects the spiritual man image. A parent with high spirituality understands and follows the family essence, its values, duties, responsibilities, family responsibilities, raising a harmonious child in the family, providing for the family financially, maintaining its peace. Highly spiritual parents bring up their children as humane, patriotic, morally pure, educated, humble, noble. In children, healthy social relationships are formed in the family under the parents, adult family members influence. The more cohesive, organized, and strong the family, the more effective its influence on the child's personality.Such a family, in addition to its own values, respects the values, society rules and norms, the child learns to live in society from an early age, and the level rises.

The family, school, community, and community organizations are key tools in shaping an individual's moral values. Especially in Uzbek homes, the people spiritual and moral values are clearly reflected in mutual respect, dignity, trust, service, love and cooperation feelings. The sacred family duty and task is not only to give birth to children, but also to bring them up in a highly spiritual, enlightened way, but also to create conditions for them to find their place in society independently.

Our first President I.A. Karimov explains that a healthy child grows up in a family with a healthy environment. "We perceive the family as an upbringing place that has a strong influence on the offspring fate, ensuring longevity. It is in the family environment that such noble qualities as respect for the elders, respect for the younger, human kindness, devotion to one's country and people are formed"2. The a healthy mindset, a healthy worldview formation in a

\footnotetext{
${ }^{1}$ Mirziyoev Sh.M. The pillar of the family and society, the grace and splendor of our lives. // The consent of our people is the highest value given to our activities. Volume 2 -T .: Uzbekistan, 2018, p.464.

${ }^{2}$ Deepening our ongoing reforms and building civil society is a key factor in our bright future. Textbook on the study of the speech of President IA Karimov at the ceremony dedicated to the 21st anniversary of the Constitution of the Republic of Uzbekistan. T. 2014 y. page 77.
} 
prosperous life development in society is directly related to the family environment. In the implementing process the family, community, school cooperation concept in young people upbringing, the family tasks are defined as follows:

- to create a healthy environment in the family, to take into account the national spirit and life way, to be a role model for children, to form a child's love for his parents, the motherland, to ensure mutual care;

- improving legal education in the family, ensuring that family members understand and abide by their rights and responsibilities;

- to provide their children with a deep secular knowledge base, to ensure that they grow up as enlightened and spiritual people;

- vocational training in accordance with market relations, economic concepts inculcation in children minds;

- creating an economic and social environment for children to be spiritually mature and physically healthy;

- to teach children to think independently, to bring them up in independence and devotion spirit to the national ideology;

- children's effective organization leisure time from a pedagogical point of view, providing them with additional education;

- creating the necessary conditions for talent buds development in their children;

- to be responsible in the family for their children to fully fulfill their duties to the school, community, state and society;

- parents to constantly improve their pedagogical and psychological knowledge;

- formation in children of moral and ethical aspects of thrift and entrepreneurship;

- ensuring responsibility for the gradual implementation of all areas of national and universal education in the family;

- inculcation of sanitary-hygienic, ecological skills, education against religious bigotry, alcoholism, drug addiction;

- is responsible for all the actions of his children in front of the family, school and community;

- to provide knowledge and professional training to children with disabilities in accordance with the requirements of life.

In the family, first of all, it is important for parents to set a personal example in the upbringing of their children. Parental behavior in the family, the culture of behavior, behavior play a key role in the formation of the spiritual upbringing of children. Therefore, parents themselves must adhere to the rules of oriental morality, have a high respect for national and spiritual values, have high universal qualities. It is in children with such positive qualities that such qualities as patriotism, self-sacrifice, loyalty, courage, bravery, endurance, composure, dignity, initiative are formed.

In the fourth direction of the Action Strategy for the five priority areas of development of the Republic of Uzbekistan for 2017-2021: "particular emphasis is placed on educating young people who are physically healthy, mentally and intellectually developed, independent-minded, loyal to the motherland, with a strong outlook on life, deepen democratic reforms and increase their social activity in the development of civil society" ${ }^{3}$. Therefore, the moral environment in the family is the oldest and most important of the moral norms that exist in human society, not only regulates the relationship between husband and wife, but is the first and foremost criterion for the formation of children as mature people.

Therefore, the upbringing of spiritually rich, morally pure, physically healthy children is carried out primarily in the family. The human qualities that accompany a person for a lifetime - kindness, goodness, diligence, creativity, devotion, loyalty, courage, etc., all begin in the family. The family prepares the ground for young people to grow up moral, honest, hardworking and honest.

Family upbringing plays an important role in the future development of children, and in this regard, there are specific rules for raising a healthy child in the family, which parents should know and children should follow:

In the family, parents, children, and other members love, understand, and respect each other;

- to consider study, work, work as the main need;

\footnotetext{
${ }^{3}$ Scientific-methodical booklet on the study of the state program for the implementation of the Action Strategy on the five priority areas of development of the Republic of Uzbekistan in 2017-2021 in the "Year of dialogue with the people and the interests of man." Tashkent Manaviyat 2017 y 203 p
} 
- not to be lazy, idle;

- adherence to a strict family schedule and decent living conditions;

- respect for the elders in the family, respect for the younger;

- psychological peace creation, healthy environment in the family;

- the formation of such qualities as independence, freedom, self-confidence in each member of the family.

Adherence to these rules will be the basis for improving relationships, strengthening the family and, in turn, raising a healthy child and becoming a citizen of society. Of course, it should always be borne in mind that the role model of parents and adults plays an important role.

Raising a child in a family should be a priority for all adults living in the family. Because the upbringing of our young children by our grandparents through national values, the heroism of our historical figures, the folklore will be more effective. That is why the head of our state tries to pay more attention to the upbringing of children and their bright future. As the first President noted, if a child receives seventy percent of the information by the age of five, the role of the family in the formation of a person's spirituality will be demonstrated. "Every sane person understands that in this bright world, as long as there is life, there is a family, as long as there is a family, there is a priceless blessing called a child, as long as there is a child, human beings always live with noble dreams and aspirations. Everything we do today is done for the our children happiness, for their bright future. But happiness is not determined only by wealth and possessions. A polite, knowledgeable and intelligent, hardworking, faithful child is the greatest wealth not only of a parent but the whole society"4.

As we raise healthy and thoughtful children in the family today, we must ensure that their spiritual world is rich, that they have a deep knowledge of our historical heritage, and that they reflect perfection. The maturity of the spiritual upbringing in the family in the comprehensive development of our children, who are gaining modern knowledge and thinking, in many respects depends on the moral issues of parents. That is why our parents themselves must strictly adhere to the highest rules of humanity and morality. Including every parent:

- to be formed as a physically and mentally mature person, ready for the comprehensive (material and spiritual) children upbringing;

- be able to deeply feel and apply the succession principle with a national identity understanding;

- have a historical memory created by ancestors and have formed a respect sense for national-spiritual values.

\section{Conclusion}

It should be noted that the focus on the healthy lifestyle formation in families at the public policy level is an important basis for the physical and spiritual development of our youth. It is in the parents upbringing who have these qualities that the younger generation will have a high spirituality level.

\section{References}

1. Mirziyoev Sh.M. The pillar of the family and society, the grace and splendor of our lives. // The consent of our people is the highest value given to our activities. Volume 2 -T .: Uzbekistan, 2018, p.464.

2. Deepening our ongoing reforms and building civil society is a key factor in our bright future. Textbook on the study of the speech of President IA Karimov at the ceremony dedicated to the 21st anniversary of the Constitution of the Republic of Uzbekistan. T. 2014 y. page $77 .$.

3. Karimov I.A. High spirituality is an invincible force. Tashkent, Manaviyat, 2008, pages 55-56.

4. Fuzailova, G. (2020). EASTERN THINKERS ON THE PEDAGOGICAL MASTERY. The Light of Islam, 2020(2), 138-144.

5. Мадраимов, А., \& Фузаилова, Г. (2008). Манбашунослик. Тошкент: Ўзбекистон файласуфлар миллий жамияти нашриёти, 52.

6. Fuzailova, G. S. (2020). САМОИДЕНТИФИКАЦИИ КАК ЛИЧНОСТНОЕ РАЗВИТИЕ БУДУЩИХ УЧИТЕЛЕЙ. Педагогика ва психологияда инновачиялар, 9(3).

\footnotetext{
${ }^{4}$ Karimov I.A. High spirituality is an invincible force. Tashkent, Manaviyat, 2008, pages 55-56.
} 